\title{
Effect of milk replacer feeding program on performance of Belgian Blue double-muscled rearing calves
}

\author{
Leo O. Fiems, Johan L. De Boever and José M. Vanacker \\ Animal Sciences Unit, Institute for Agricultural and Fisheries Research (ILVO), Melle, Belgium
}

\begin{abstract}
One hundred and four Belgian Blue double-muscled calves were divided into four groups to examine the effects of different milk replacer (MR) programs. Calves in treatment group 1 received a MR diet reconstituted at $125 \mathrm{~g} / \mathrm{l}$, fed at $10 \%$ of their initial live weight in two meals daily. Weaning occurred abruptly at a concentrate intake of $0.5 \mathrm{~kg} / \mathrm{d}$. Treatment 2 was similar to treatment 1, except that weaning occurred at a concentrate intake of $0.75 \mathrm{~kg} / \mathrm{d}$. Treatment 3 was similar to treatment 2, except that MR was fed once daily at $5 \%$ of initial body weight from a concentrate intake of $0.5 \mathrm{~kg} / \mathrm{d}$ onwards. Treatment 4 was similar to treatment 3, except that MR at a concentration of $200 \mathrm{~g} / \mathrm{l}$ was fed once daily from the third week until a concentrate intake of $0.5 \mathrm{~kg} / \mathrm{d}$. Similar concentrates and grass hay were fed. Pre-weaning gain averaged $0.51,0.57,0.56$ and $0.53 \mathrm{~kg} / \mathrm{d}$, respectively $(P<0.05 ; \mathrm{SEM}$ : 0.01$)$. Daily nutrient intake was lowest for treatment 1 . No effect on diarrhoea was found. Postweaning gain did not differ among treatments. Daily gain during the whole rearing period ( 20 weeks) averaged $0.83 \mathrm{~kg}$ and was not affected by treatment. Calves assigned to treatment 1 had a lower daily intake of MR, while feed efficiency tended to be worse. Weaning can be successfully accelerated by skipping over a meal when concentrate intake exceeded $0.5 \mathrm{~kg} / \mathrm{d}$, or by combining one MR meal daily with an increased concentration of $200 \mathrm{~g} / \mathrm{l}$ from an age of three weeks onwards.
\end{abstract}

Keywords: double-muscled calves, milk replacer concentration, meals per day

Abbreviations: BBDM: Belgian Blue double-muscled, CL: concentrate intake level, DM: dry matter, LW: live weight, MR: milk replacer, SEM: standard error of mean

Archiv Tierzucht 56 (2013) 105, 1039-1051

doi: $10.7482 / 0003-9438-56-105$

Corresponding author:

Leo Fiems; email: leo.fiems@ilvo.vlaanderen.be

Animal Sciences Unit, Institute for Agricultural and Fisheries Research (ILVO), Scheldeweg 68, 9090 Melle, Belgium

(c) 2013 by the authors; licensee Leibniz Institute for Farm Animal Biology (FBN), Dummerstorf, Germany. This is an Open Access article distributed under the terms and conditions of the Creative Commons Attribution 3.0 License (http://creativecommons.org/licenses/by/3.0/).
Received: 24 July 2013

Accepted: 20 November 2013
Online: 2 December 2013 


\section{Introduction}

Pre-weaning growth rate (Miller et al. 1999) or weaning weight (Freking \& Marshall 1992) are both positively correlated with milk intake by the young beef calf. Robison et al. (1978) reported a correlation between weaning weight and total milk intake of 0.63 . Similar effects were found in Belgian Blue double-muscled (BBDM) calves, with a correlation coefficient of 0.81 between average daily milk intake and pre-weaning live weight (LW) gain (Fiems et al. 2008). However, milk yield of BBDM dams is often low or even insufficient for calf rearing, so that calves are mostly reared on a milk replacer (MR) diet. Feeding MR is labour-intensive and time-consuming and MR is more expensive than solid feeds. Therefore, management systems resulting in earlier weaning can be interesting. Weaning involves the change from a milk diet to solid feed and this transition can be stressful. Rumen development is a normal physiological process and can be considered necessary for the welfare of the calf (Stull \& Reynolds 2008). The development of the rumen depends on the solid feed availability. Therefore, solid feed intake can be used as a criterion to determine when to wean rearing calves. Previous studies showed that weaning of BBDM calves should be delayed until a daily concentrate intake of at least $0.75 \mathrm{~kg}$ for reasons of welfare, although performance was hardly improved in comparison with weaning at a daily concentrate intake of $0.5 \mathrm{~kg}$ (Fiems et al. 2005). Abrupt weaning at a daily concentrate intake of 0.5 or $0.75 \mathrm{~kg}$ was used as a negative or a positive control group, respectively, in this experiment. Digestive upsets may occur when the capacity of the abomasum is exceeded with the result of excess milk flowing back into the rumen, or milk moving too rapidly to the intestines. Because of the reduced organ size of BBDM animals (Fiems 2012), they may be more prone to digestive disorders than calves from other breeds. Belgian Blue double-muscled animals are characterized by a lower intake capacity compared to non-double-muscled ones (Fiems et al. 1997). Although solid feed was freely available, BBDM calves did not compensate a lower milk intake by an increased concentrate and hay intake during the first four months of life (Fiems et al. 2008). Consequently, BBDM calves are commonly weaned at a higher age than non-double-muscled calves. An earlier initiation of solid feed intake in calves fed milk according to a step-down method stimulates the metabolic and physical development of the rumen in comparison with feeding milk at a constant amount (Khan et al. 2007a). Therefore, the effect of gradual weaning (step-down regimen) was investigated when MR was fed once daily from two different ages onwards. Only for the youngest calves, dry matter (DM) concentration of the MR was increased because of the reduced fluid intake. Increasing DM concentration in the MR may increase pre-weaning growth rate (Jenny et al. 1982).

The objective of this experiment was to examine the effect of different MR feeding programs on the duration of the pre-weaning period, LW gain and feed intake in BBDM newborn calves.

\section{Material and methods}

Experimental procedures were according to the standards of the European Union for the use of experimental animals (Anonymous 1986). 


\section{Animals, housing and management}

One hundred and four BBDM female calves with an initial age and LW of 7.0 \pm 2.1 days and $53.7 \pm 7.2 \mathrm{~kg}$, respectively, and born out of the beef cow herd of the institute (ILVO - Animal Sciences Unit, Melle, Belgium), were used to investigate the effect of the milk feeding program on animal performance during the rearing period. Calves were introduced when they were between three and nine days old. Colostrum was fed the first day after birth followed by cow milk for the next two days and MR afterwards. The experimental period lasted 140 days, including a pre- and a post-weaning period. Throughout the experiment calves were confined in individual $1.4 \times 2.3 \mathrm{~m}$ outdoor hutches with a $1.3 \times 1.75 \mathrm{~m}$ fenced walking area. A single weighing occurred at the start of the experiment and at one and two weeks after weaning, with a double weighing at weaning and at the end of the rearing period. Furthermore, calves were weighed at two or four-week intervals before and after the eighth experimental week, respectively. Beside the milk diet all calves received a similar concentrate and grass hay. Concentrate ingredients were $(\mathrm{g} / \mathrm{kg})$ : barley: 211, beet pulp: 200, palm kernel cake: 200, soybean meal: 224.2, beet molasses: 60 , pollards: 51, lard: 11, limestone: 11.3, dicalcium phosphate: 2.1 , salt: 1.9 , vitamin and trace element premix: 17.5 , binder (lignosulphonate): 10. Ingredients were ground to pass a $6-\mathrm{mm}$ sieve, and pelleted using a $6 \mathrm{~mm}$ die. Concentrate intake was levelled off at a maximum of $3 \mathrm{~kg}$ per day. Grass hay was fed ad libitum and drinking water was always available.

\section{Experimental treatments}

Calves were divided into four comparable groups (26 calves per group) based on initial LW. They were fed a MR diet (50\% skim milk powder, $26 \%$ whey powder, $16.5 \%$ vegetable oil (mixture of palm oil, coconut oil and soybean oil), and $5 \%$ wheat starch) at $40{ }^{\circ} \mathrm{C}$ by teat-bottle. Calves of treatments 1 and 2 received a milk diet reconstituted at $125 \mathrm{~g}$ MR powder per litre, fed at a constant daily level of $10 \%$ of their initial LW, and equally divided over a morning and

Table 1

Schematic lay-out of the experimental treatments

\begin{tabular}{|c|c|c|c|c|}
\hline \multirow[b]{2}{*}{ Timing } & \multicolumn{4}{|c|}{ Treatments } \\
\hline & $\begin{array}{c}1 \\
\text { Early and abrupt } \\
\text { weaning }\end{array}$ & $\begin{array}{c}2 \\
\text { Abrupt weaning at higher } \\
C L\end{array}$ & $\begin{array}{c}3 \\
\text { Gradual weaning at } \\
\text { higher } \mathrm{CL}\end{array}$ & $\begin{array}{c}4 \\
\text { Gradual weaning at } \\
\text { higher } \mathrm{CL} \text {, reduced } \mathrm{MR} \\
\text { with increased } \\
\text { concentration }\end{array}$ \\
\hline Week 1-2 & \multicolumn{4}{|c|}{ MR: $125 \mathrm{~g}$ powder $/ \mathrm{L} ; 5 \%$ of initial LW in the morning $\& 5 \%$ of initial LW in the evening } \\
\hline $\begin{array}{l}\text { Week } 3 \text { till a weekly } \\
\text { concentrate intake of } \\
3.5 \mathrm{~kg}\end{array}$ & \multicolumn{3}{|c|}{$\begin{array}{l}\text { MR: } 125 \mathrm{~g} \text { powder } / \mathrm{L} ; 5 \% \text { of initial LW in the morning } \& 5 \% \text { of initial LW } \\
\text { in the evening }\end{array}$} & $\begin{array}{c}\text { MR: } 200 \mathrm{~g} \text { powder } / \mathrm{L} ; 5 \% \\
\text { of initial LW once daily in } \\
\text { the morning }\end{array}$ \\
\hline $\begin{array}{l}\text { From a weekly } \\
\text { concentrate intake of } 3.5 \\
\text { to } 5.25 \mathrm{~kg}\end{array}$ & \multirow[t]{2}{*}{$\begin{array}{l}\text { Weaning } \\
(C L 0.5)\end{array}$} & $\begin{array}{l}\text { MR: } 125 \mathrm{~g} \text { powder } / \mathrm{L} ; 5 \% \text { of } \\
\text { initial } L W \text { in the morning \& } \\
5 \% \text { of initial } L W \text { in the } \\
\text { evening }\end{array}$ & \multicolumn{2}{|c|}{$\begin{array}{c}\text { MR: } 125 \mathrm{~g} \text { powder } / \mathrm{L} ; 5 \% \text { of initial LW once daily in } \\
\text { the morning }\end{array}$} \\
\hline $\begin{array}{l}\text { From a weekly } \\
\text { concentrate intake of } \\
5.25 \mathrm{~kg}\end{array}$ & & & $\begin{array}{l}\text { Weaning } \\
(C L 0.75)\end{array}$ & \\
\hline
\end{tabular}

The bold line denotes a similar post-weaning management, CL: concentrate intake level (kg/day), MR: milk replacer, LW: live weight 
an evening meal. Weaning occurred abruptly when the weekly concentrate intake achieved 3.5 (concentrate intake level (CL) 0.5; Treatment 1: early and abrupt weaning) or $5.25 \mathrm{~kg}(\mathrm{CL}$ 0.75; Treatment 2: abrupt weaning at higher $\mathrm{CL}$ ). Treatment 3 (gradual weaning at higher $\mathrm{CL}$ ) was similar to treatment 2, except that the MR diet was fed once daily in the morning ( $5 \%$ of initial LW) when a weekly concentrate intake of $3.5 \mathrm{~kg}$ was achieved. Treatment 4 (gradual weaning at higher $\mathrm{CL}$ with a reduced fluid intake in combination with an increased DM concentration of the MR) was similar to treatment 3, except that MR diet was fed once daily from the third week onwards, and MR concentration amounted to $200 \mathrm{~g}$ powder per litre until a weekly concentrate intake of $3.5 \mathrm{~kg}$. Treatments are shown schematically in Table 1. Faeces consistency was observed daily.

\section{Analytical procedures}

MR powder, concentrate and hay were sampled monthly and pooled at the end of the experiment. Chemical composition was determined using reference methods for ash (ISO 2002), moisture (Anonymous 1971), protein (ISO 2005) and fat (ISO 1999). Neutral detergent fibre (NDF) was analysed using an Ankom 200 fibre analyser (Ankom Technology, Macedon NY, USA). Heat-stable a-amylase and sodium sulfite were added to the neutral detergent solution. Neutral detergent fibre was expressed on an ash-free base (Van Soest et al. 1991). Net energy (NE) was estimated from the cellulase in vitro organic matter digestibility (De Boever et al. 1999). Mean composition and NE value of the feeds are shown in Table 2.

Table 2

Chemical composition and energy value of the feeds fed to Belgian Blue double-muscled calves during the rearing period

\begin{tabular}{lccc}
\hline & Milk replacer & Concentrate & Grass hay \\
\hline Dry matter, DM; g/kg & 964 & 903 & 896 \\
Composition of DM, g/kg & & & \\
$\quad$ Crude protein & 221 & 206 & 139 \\
Crude fat & 191 & 40 & 14 \\
Crude fibre & & 124 & 282 \\
Ash & 76 & 73 & 97 \\
NDF & & 263 & 569 \\
ADF & & 144 & 317 \\
ADL & 10.7 & 25 & 29 \\
Net energy*, MJ/kg DM & 7.0 & 5.8 \\
\hline
\end{tabular}

*The net energy was estimated using the cellulose in vitro organic matter digestibility (De Boever et al. 1999).

\section{Statistical analysis}

The Statistica software (StatSoft 2009, StatSoft Inc., Tulsa, OK, USA) procedure for general linear models was used for a one-way analysis of variance. Differences between treatments were tested for significance by the Newman-Keuls test. Calf was used as the statistical unit. Results are presented as least squares means \pm standard error. The effect of abrupt weaning vs. gradual weaning (W) was studied by comparing the results of treatment 1 and 2 with those of treatments 3 and 4 . The effect of CL was investigated by comparing the results of treatment 
1 with those of treatments 2, 3 and 4 . The effect of a reduced MR supply at an increased DM concentration (Treatment 4) on energy intake and LW gain during the 3rd and the 4th experimental week was compared with the effect of the MR feeding program of treatments 1, 2 and 3. Within CL 0.75 once daily MR feeding (treatments 3 and 4) was compared with twice daily milk feeding (treatments 2). Treatment effects were presented as significant when $P<0.05$ and trends were identified at $0.05<P<0.10$. Calves developing scours during the preweaning period and receiving electrolytes were assigned a value of 1 while the others were assigned a value of zero. The chi square test was used to compare the frequency of scours. Pearson's correlations between daily concentrate intake during the week prior to weaning and daily gain during the first week after weaning, the first two weeks after weaning and the entire rearing period were calculated. Pearson's correlations between intake of total amounts of MR, concentrate and hay were also calculated. A Pearson's correlation between daily gain during the first week after the adaptation of the MR concentration and concentrate intake during the first two weeks was calculated for treatment 4.

\section{Results}

\section{Pre-weaning period}

Pre-weaning growth rate $(0.51 \mathrm{~kg} / \mathrm{d})$ and LW at weaning $(76.9 \mathrm{~kg})$ were lower for calves weaned at a weekly concentrate intake of $3.5 \mathrm{~kg}$ compared to a weekly concentrate intake of $5.25 \mathrm{~kg}(0.56 \mathrm{~kg} / \mathrm{d}$ and $84.6 \mathrm{~kg}$, respectively; treatments 2, 3 and 4; CL effect; Table 3). A lower daily concentrate intake and a small tendency for a lower hay intake were observed for $\mathrm{CL}$ 0.5 . The pre-weaning period was shorter for treatment 1 in comparison with treatments 2 and 3. The time span to achieve a CL 0.5 for treatments 2, 3 and 4 amounted to 51.2, 47.7 and 46.0 days, respectively, and was not different between treatments. Afterwards, the period to increase $C L$ from 0.5 to 0.75 averaged 8.6, 8.1 and 6.5 days, respectively, and was neither significantly different $(P>0.1)$. As a consequence, groups 3 and 4 had a similar management during only 20.5 days of the pre-weaning period.

No calves were weaned before the 5 th experimental week. Total NE intake during the 3rd and the 4th experimental week from MR, concentrate and MR plus concentrate averaged 77.9, 17.2 and $95.1 \mathrm{MJ}$, respectively, for calves receiving a reduced amount of MR at an increased concentration in one meal daily (treatment 4). The mean total NE intake for treatments 1,2 and 3 during this period amounted to $87.8,16.7$ and $104.5 \mathrm{MJ}$, respectively. Net energy intake from MR, and from MR plus concentrate was for lower for treatment $4(P<0.05)$, while NE intake from concentrate was not significantly increased, compared to the mean NE intake from concentrate of calves subjected to treatments 1,2 and 3. Although NE intake from MR plus concentrate was different, LW gain during the $3 \mathrm{rd}$ and the 4 th experimental week was not different between group 4, on the one hand, and groups 1, 2 and 3, on the other hand $(P>0.1)$.

Weaning abruptly or gradually (W effect) did not significantly affect $\mathrm{LW}$ at weaning (82.4 vs. $82.9 \mathrm{~kg})$ and pre-weaning growth rate $(0.54 \mathrm{vs} .0 .55 \mathrm{~kg} / \mathrm{d})$. Within $\mathrm{CL} 0.75, \mathrm{LW}$ at weaning tended to be lower when MR was fed once daily (Groups 3 and 4) compared to twice daily feeding (Group 2; 82.9 vs. $87.9 \mathrm{~kg} ; P=0.063$ ), but the pre-weaning period also tended to be 


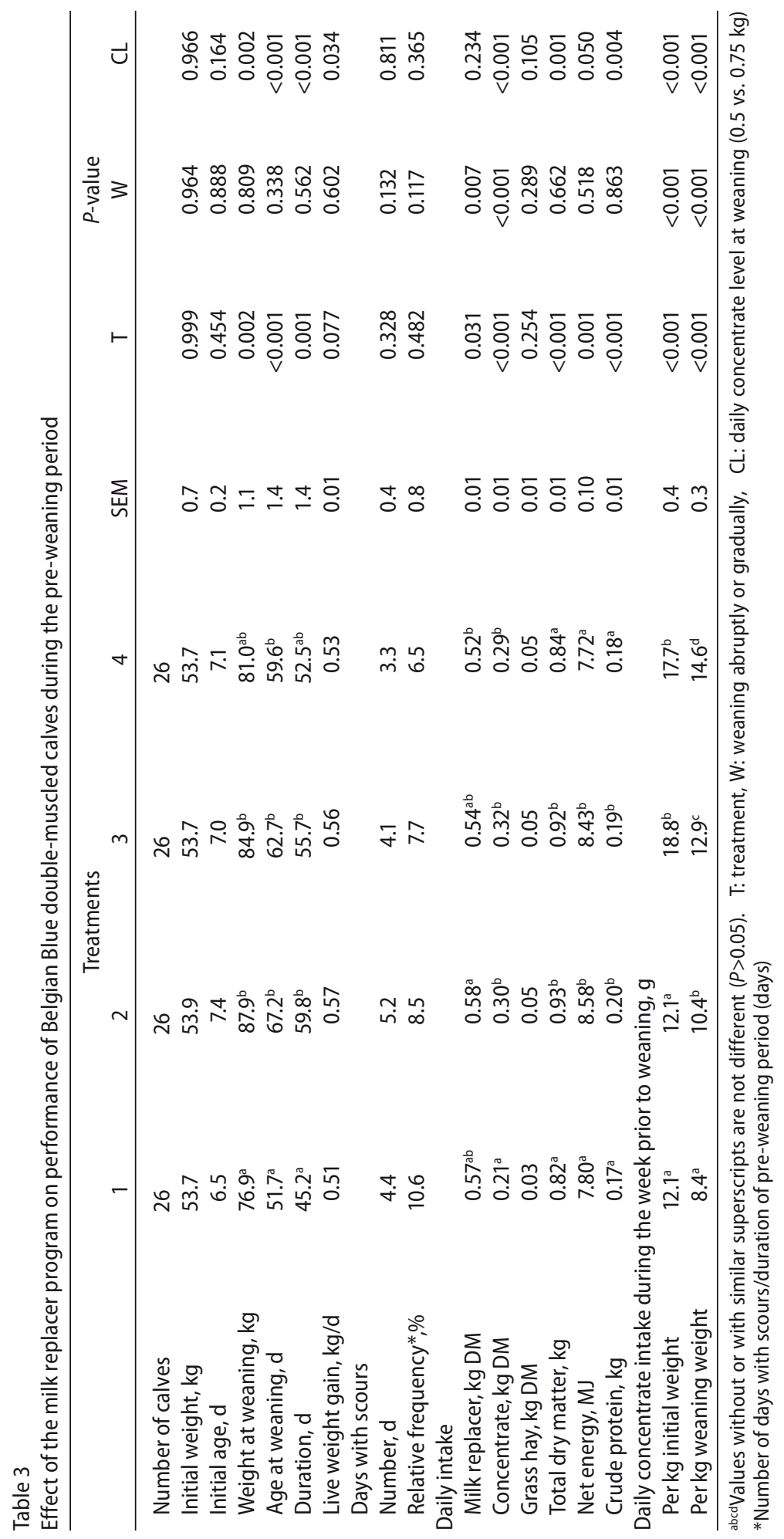


shorter ( 54.1 vs. 59.8 days; $P=0.071$ ), so that growth rate was not affected. Early weaned calves (treatment 1) had a lower daily intake of concentrate, DM, energy and protein than calves subjected to treatments 2 and 3, but values did not differ from treatment 4, except concentrate intake. Daily MR intake was lower for treatment 4 than for treatment 2.

Feeding MR once daily at an increased DM concentration (treatment 4) did not affect the incidence of scours compared to other treatments (Table 3).

Relative daily concentrate intake during the week prior to weaning $(\mathrm{g} / \mathrm{kg}$ weaning $\mathrm{LW}$ ) was different between treatments, even when the same absolute $C L$ was applied for weaning in treatments 2,3 and 4 . Expressing concentrate intake per $\mathrm{kg}$ initial $\mathrm{LW}$ resulted in a similar intake for treatments 1 and 2, which was lower than the intake for treatments 3 and 4 . Concentrate intake during the week prior to weaning, expressed per kg initial $L W(r=0.216 ; P=0.028)$ or weaning $\mathrm{LW}(\mathrm{r}=0.224 ; P=0.022)$ was only weakly correlated with growth rate during the first week after weaning. A weak correlation between concentrate intake $(\mathrm{g} / \mathrm{kg}$ weaning $\mathrm{LW})$ and growth rate during the first two weeks after weaning was observed $(r=0.185 ; P<0.060)$. The correlation between concentrate intake prior to weaning and growth rate during the entire rearing period was close to 0 . One calf assigned to treatment 4 lost weight during the first week after the adaptation of the MR concentration. No significant correlation between daily gain during the first week after the adaptation of the MR concentration and concentrate intake during the first two weeks of the pre-weaning period was found.

\section{Post-weaning period}

Post-weaning growth rate, final age and final LW were not different between treatments $(P>0.1$; Table 4). The post-weaning period was longest for treatment $1(P<0.001)$, but this was due to the shorter pre-weaning period. Daily intake data were unaffected by treatment.

Weaning abruptly or gradually only tended to affect growth rate during the first weeks after weaning. All parameters were affected by $\mathrm{CL}$, except final $\mathrm{LW}$, final age and hay intake. Calves weaned at $C L 0.5$ gained slower during the first week after weaning than for $C L$ 0.75: 0.57 vs. $0.75 \mathrm{~kg} / \mathrm{d}(P=0.006)$. Similar results were found for the first two weeks after weaning: 0.75 vs. $0.89 \mathrm{~kg} / \mathrm{d}(P=0.006)$. One calf assigned to treatment 1 lost weight during the first week after weaning.

\section{Entire rearing period}

Growth rate during the whole rearing period was not affected by treatment, weaning method $(W)$ or $C L$ and averaged $0.83 \mathrm{~kg} / \mathrm{d}$. Intakes of feed and nutrients were not affected by treatment, except MR. Concentrate intake level exerted a significant effect on the efficiency of DM (2.52 vs. $2.43 \mathrm{~kg}$, respectively for $\mathrm{CL} 0.5$ and 0.75 ) and crude protein ( $0.50 \mathrm{vs} .0 .48 \mathrm{~kg}$ ) utilisation, with a trend for a lower efficiency of energy utilisation (18.1 vs $17.6 \mathrm{MJ} ; P=0.092$ ). No effect of abrupt or gradual weaning on the efficiency of nutrient use was observed.

Total concentrate-DM intake was inversely related with the amount of MR-DM consumed: $\mathrm{r}=-0.789 ; P<0.001$. Total intakes of MR-DM and hay-DM were not correlated $(P>0.1)$, while total intakes of concentrate-DM and hay-DM were moderately correlated: $r=0.342 ; P<0.001$. 


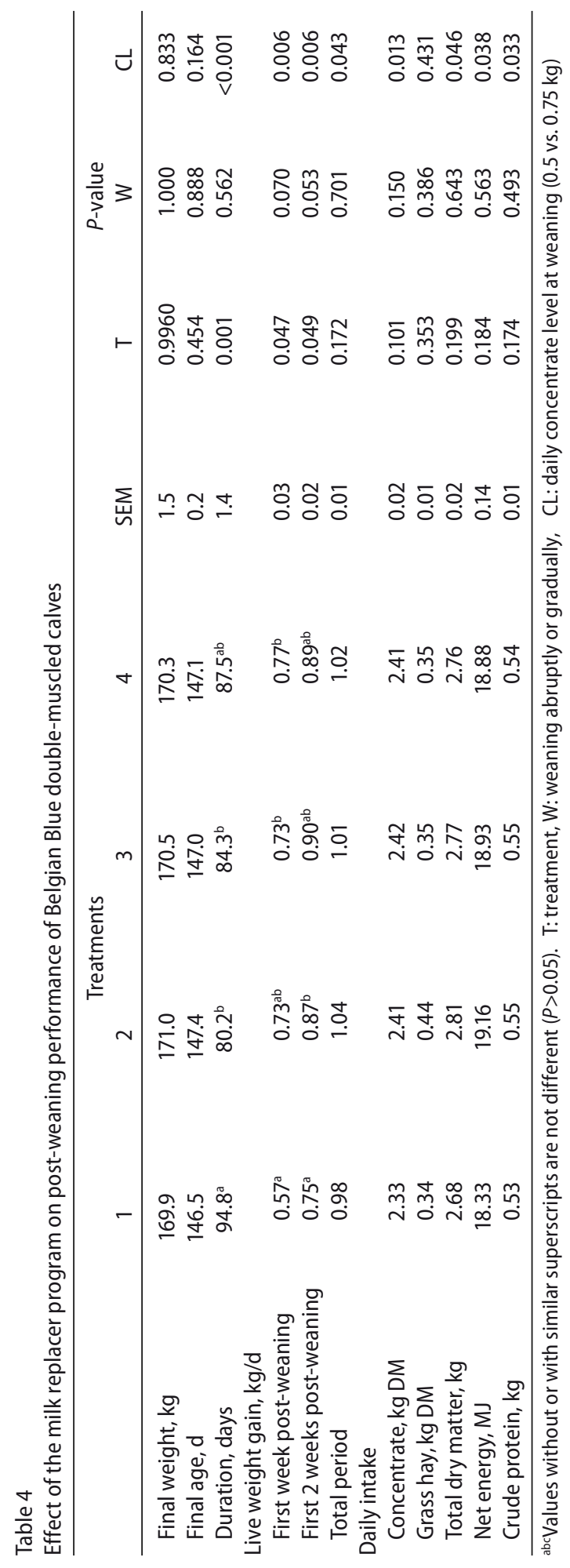




\section{Discussion}

\section{Pre-weaning performance}

The MR feeding program clearly affected growth rate, with the widest range of gain between groups 1 and 2. Weaning at $\mathrm{CL} 0.5$ resulted in a shorter pre-weaning period and a lower preweaning growth rate. Although $\mathrm{CL}$ at weaning was different between treatments 1 and 2 (0.5 vs. $0.75 \mathrm{~kg} / \mathrm{d}$ ), concentrate intake during the week prior to weaning was similar, amounting to $12.1 \mathrm{~g} / \mathrm{kg}$ initial LW. Greenwood et al. (1997) proposed dry feed intake as a percentage of birth weight as a criterion to wean dairy calves, which is not confirmed by our results, obtained with calves of a specialized beef breed. This means that there is no optimal weaning method to realize maximum calf performances. A similar CL of $0.75 \mathrm{~kg} / \mathrm{d}$ at weaning (treatments 2,3 and 4) exerted a significant effect on concentrate intake per $\mathrm{kg}$ initial or weaning LW. Therefore, these results suggest that an absolute concentrate intake, e.g. a $\mathrm{CL}$ of $0.75 \mathrm{~kg} / \mathrm{d}$, may be more appropriate in BBDM calves than a feed intake as a percentage of birth weight. Within treatments applying weaning at a $\mathrm{CL}$ of $0.75 \mathrm{~kg} / \mathrm{d}$, differences in concentrate intake can be related to the step-down feeding of the MR. However, a step-down method as such is not a guarantee for an increased concentrate intake, because of a possible interaction between the method of weaning and the amount of the milk diet (Khan et al. 2007b, Sweeney et al. 2010). Considerably higher amounts of the milk diet were fed in experiments of Khan et al. (2007b) and Sweeney et al. (2010): $20 \%$ of LW or $12 \mathrm{~kg} / \mathrm{d}$, respectively, in comparison with $10 \%$ of LW in our experiment. Hill et al. (2012) reported that over $0.7 \mathrm{~kg} \mathrm{DM}$ from milk or MR daily will result in a reduction of the post-weaning growth rate by depressing starter intake, but gradual weaning over two to three weeks could avoid this reduction. However, this threshold DM intake of $0.7 \mathrm{~kg} / \mathrm{d}$ DM from the MR was not consumed by the calves assigned to treatments 1 and 2. Gradual weaning resulted in a higher pre-weaning intake of concentrate in comparison with abrupt weaning in our experiment, although intakes of total DM, energy and protein were not different. The lower concentrate intake of calves weaned abruptly was in accordance with results of Sweeney et al. (2010), but the similar energy intake in our experiment was not confirmed by the latter authors. This can be explained by the higher intake of milk and weaning at a fixed age in the experiment of Sweeney et al. (2010).

Treatment 4 was a combination of once daily MR feeding during part of the rearing period, gradual weaning and a reduced fluid intake combined with an increased DM concentration of the MR. Once daily feeding can increase outbreaks of diarrhoea (Gleeson et al. 2007). Dry matter concentration cannot be increased in case of whole milk feeding. Because of the smaller organ size in double-muscled animals (Fiems 2012) high amounts of MR may accelerate the overload of the abomasum, which may increase the occurrence of diarrhoea. Therefore we increased DM concentration of the MR to avoid digestive upsets. Dry matter concentration of the reconstituted milk had a positive effect on pre-weaning LW gain, but overall LW gain was not affected by DM concentration in experiments of Jenny et al. (1982). These authors also found that pre-weaning starter intake decreased, while the incidence of scours increased linearly with increasing DM concentration. Jenny et al. (1982) fed MR once daily at $10 \%$ of LW, while MR at $200 \mathrm{~g}$ powder per litre was fed once daily at $5 \%$ of LW to BBDM calves. Frequency of diarrhoea was not increased in the current experiment. In an experiment of Kehoe et al. (2007) calves were switched over from twice daily feeding at $10 \%$ 
of birth weight to once daily feeding at $10 \%$ of birth weight at 15 days of age, and MR was further reduced to $5 \%$ of birth weight one week prior to weaning. No differences in growth rate and feed efficiency were found.

\section{Post-weaning performance}

Weight loss during the first week after weaning, as observed for one calf of group 1, and the lower LW gain during the first weeks after weaning can be considered as an indication of a negative or a lower energy balance, respectively, owing to an insufficient feed intake when the milk diet was omitted, resulting in weaning stress. A negative energy balance should be avoided (EFSA 2006). Previous experiments did not reveal a detrimental effect of a $\mathrm{CL}$ of $0.5 \mathrm{~kg} / \mathrm{d}$ at weaning on subsequent development (Fiems et al. 2005). Calves subjected to treatment 1 in the current experiment were also able to compensate for the lower weaning LW at the end of the post-weaning period, although calves have a reduced capacity to compensate for a lower feeding level during calf hood (Berge 1991).

\section{Performance during the entire rearing period}

The average daily gain of $0.83 \mathrm{~kg}$ was far above the threshold of $0.6 \mathrm{~kg}$ to safeguard the development of double-muscled females during their subsequent life (Fiems \& De Brabander 2009). Overall rate of gain was not affected by treatment, weaning method or CL. However, the efficiencies of DM and protein utilisation were reduced by $\mathrm{CL} 0.5$, with a tendency for a lower energy efficiency. The reason for this lower efficiency is not clear, but it cannot be due to a lower dietary protein concentration. Winter (1978) also found a tendency for a lower feed efficiency for early weaning of dairy calves. Weaning occurred earlier in the experiment of Winter (1978) than in our experiment: two vs. five weeks of age. The worse efficiency can be due to the low digestive capacity in calves during the first two to three weeks of life (Longenbach \& Heinrichs 1998). Because calves in our experiment were older at weaning, this reason cannot be responsible for the reduced efficiency for early weaned calves, unless the development of the digestive tract is retarded in double-muscled calves.

A high intake of milk or MR often lowers concentrate intake (Huber et al. 1984, Quigley et al. 2006). This phenomenon is confirmed by the results of the current experiment where we found a significant negative correlation between the DM intake of MR and concentrate. The consequence of a reduced MR feeding is that calves are reared at lower feed costs, due to savings in MR powder. Assuming current prices for MR, concentrate and hay of 2.4, 0.4 and $0.1 € / \mathrm{kg}$, respectively, and taking the actual feed intake into account, results in lower total costs and a lower feed cost per kg LW gain (Table 6). Furthermore, a shorter pre-weaning period (Table 3) and feeding MR once daily (treatments 3 and 4) may also be labour saving. Galton \& Brakel (1976) reported that calves fed once daily required 39\% less labour in milk feeding than calves fed twice daily. The lower NE intake from MR plus concentrate during the $3 \mathrm{rd}$ and the 4th experimental week in group 4 in comparison with the intake in the other groups, and the fact that one calf lost LW during the 3rd week, suggest that it may be difficult to further accelerate weaning without detrimental effects on animal performance. This is in agreement with previous results from suckling calves, where concentrate intake hardly compensated a lower milk intake (Fiems et al. 2008). 


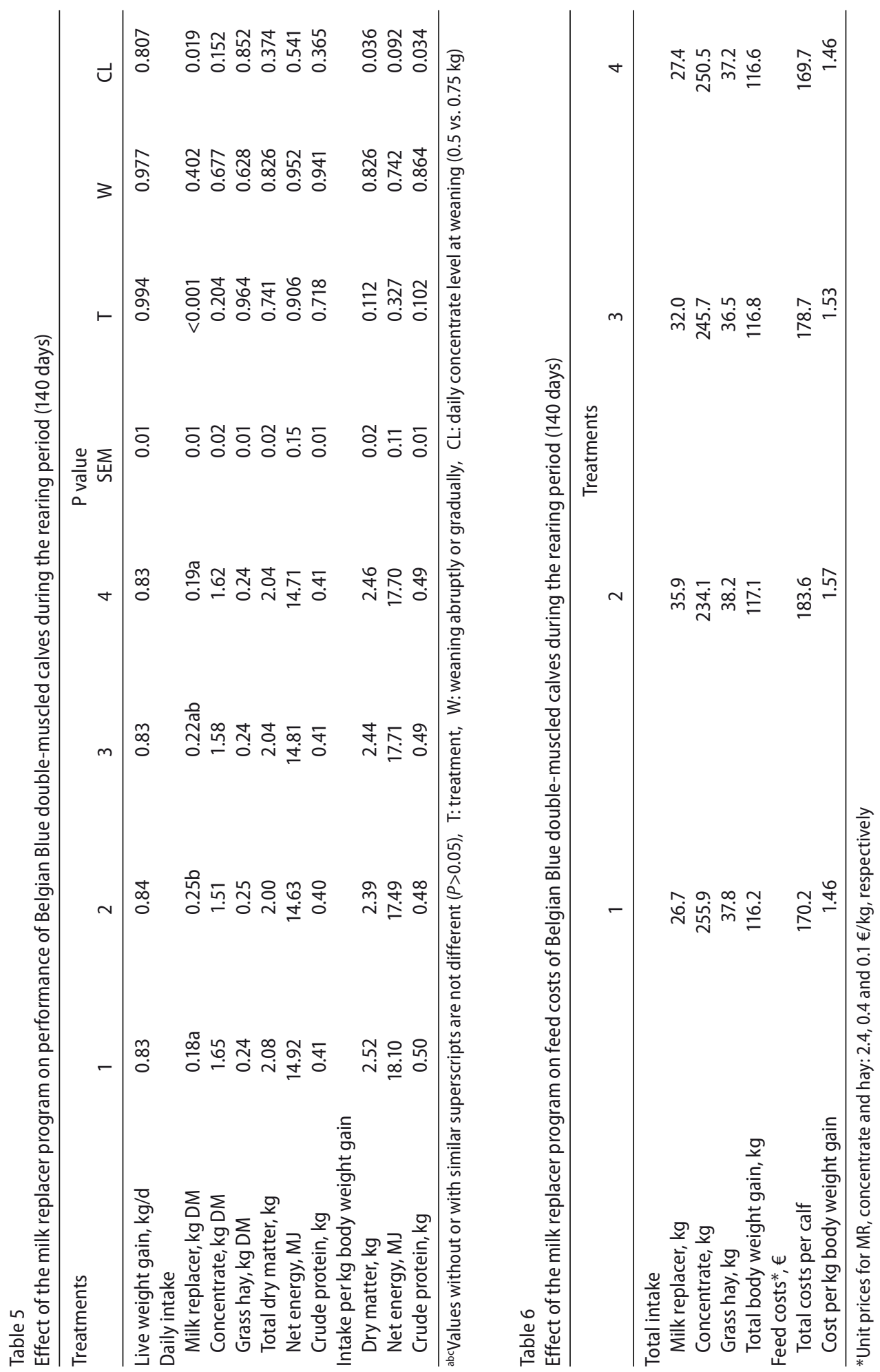


It can be concluded that daily gain of BBDM calves during the entire rearing period and the occurrence of diarrhoea during the pre-weaning period were not affected by the MR feeding program, although weaning at a daily concentrate intake of $0.5 \mathrm{~kg}$ resulted in a lower preweaning growth and a lower growth rate during the first weeks after weaning in comparison with weaning at a daily concentrate intake of $0.75 \mathrm{~kg}$. Abrupt weaning did not influence preweaning growth rate, but daily intake of MR was higher and daily intake of concentrate was lower in comparison with gradual weaning. Feed was less efficiently converted during the entire rearing period for early weaned calves. Weaning can be successfully accelerated in BBDM calves by skipping over a MR meal when concentrate intake exceeded $0.5 \mathrm{~kg} / \mathrm{d}$, or by a combination of a once daily MR feeding with an increased concentration of $200 \mathrm{~g} / \mathrm{L}$ from the age of three weeks onward.

\section{Acknowledgements}

The authors greatly acknowledge Esther Beeckman, Piet Van Laere and Tim De Cock for their skilled technical assistance.

\section{References}

Anonymous (1986) Council Directive 86/609/EEC of 24 November 1986 on the approximation of laws, regulations and administrative provisions of the Member States regarding the protection of animals used for experimental and other scientific purposes. Official Journal of the European Communities 29, L 358, 1-28

Anonymous (1971) Directive 71/393 EEC, Community methods of analysis for the official control of feedingstuffs. Official Journal of the European Communities 14, L 279, 7-18

Berge $P$ (1991) Long-term effects of feeding during calfhood on subsequent performance in beef cattle (a review). Livest Prod Sci 28, 179-201

De Boever JL, Cottyn BG, De Brabander DL, Vanacker JM, Boucqué CV (1999) Equations to predict digestibility and energy value of grass silages, maize silages, grass hays, compound feeds and raw materials for cattle. Nutr Abstr Rev 69, 835-850

EFSA (2006) Scientific Opinion on The risks of poor welfare in intensive calf farming systems. An update of the Scientific Veterinary Committee Report on the Welfare of Calves. EFSA J 4, 366, 36 pp

Fiems LO (2012) Double Muscling in Cattle: Genes, Husbandry, Carcasses and Meat. Animals 2, $472-506$

Fiems LO, Cottyn BG, Boucqué CV, Bogaerts DF, Van Eenaeme C, Vanacker JM (1997) Effect of beef type, body weight and dietary protein content on voluntary feed intake, digestibility, blood and urine metabolites and nitrogen retention. J Anim Physiol Anim Nutr 77, 1-9

Fiems L, De Boever J, De Campeneere S, Vanacker J, De Brabander D (2005) Effect of daily concentrate intake at weaning on performance of belgian blue double-muscled rearing calves. Arch Anim Nutr 59, 397-404

Fiems LO, De Brabander DL (2009) Optimum growth rate of Belgian Blue double-muscled replacement heifers. S Afr J Anim Sci 39 (Suppl.), 6-10

Fiems LO, Van Caelenbergh W, De Campeneere S, De Brabander DL (2008) Effect of dam factors on milk intake and performance of Belgian Blue suckling calves. Animal 2, 135-140

Freking BA, Marshall DM (1992) Interrelationships of heifer milk production and other biological traits with production efficiency to weaning. J Anim Sci 70, 646-655

Galton DM, Brakel WJ (1976) Influence of Feeding Milk Replacer Once Versus Twice Daily on Growth, Organ Measurements, and Mineral Content of Tissues. J Dairy Sci 59, 944-948

Gleeson DE, O'Brien B, Fallon RJ (2007) Feeding of Cold Whole Milk Once Daily to Calves in a Group and Its Effect on Calf Performance, Health, and Labour Input. Int J Appl Res Vet Med 5, 97-104 
Greenwood RH, Morrill JL, Titgemeyer EC (1997) Using Dry Feed Intake as a Percentage of Initial Body Weight as a Weaning Criterion. J Dairy Sci 80, 2542-2546

Hill TM, Bateman II HG, Aldrich JM, PAS, Schlotterbeck RL (2012) Methods of reducing milk replacer to prepare dairy calves for weaning when large amounts of milk replacer have been fed. Prof Anim Sci 28, 332-337

Huber JT, Silva AG, Campos OF, Mathieu CM (1984) Influence of Feeding Different Amounts of Milk on Performance, Health, and Absorption Capability of Baby Calves. J Dairy Sci 67, 2957-2963

ISO (1999) Animal feeding stuffs - Determination of fat content. ISO standard 6492. International Standards Organization, Geneva, Switzerland, 9 pp

ISO (2002) Animal feeding stuffs - Determination of crude ash. ISO standard 5984. International Standards Organization, Geneva, Switzerland, $6 \mathrm{pp}$

ISO (2005) Animal feeding stuffs - Determination of nitrogen content and calculation of crude protein content - Part 2: Block digestion/steam distillation method. ISO standard 5983-2. International Standards Organization, Geneva, Switzerland, 14 pp

Jenny BF, Van Dijk HJ, Grimes LW (1982) Performance of Calves Fed Milk Replacer Once Daily at Various Fluid Intakes and Dry Matter Concentrations. J Dairy Sci 65, 2345-2350

Kehoe SI, Dechow CD, Heinrichs AJ (2007) Effects of weaning age and milk feeding frequency on dairy calf growth, health and rumen parameters. Livest Sci 110, 267-272

Khan MA, Lee HJ, Lee WS, Kim HS, Ki KS, Hur TY, Suh GH, Kang SJ, Choi, YJ (2007a) Structural Growth, Rumen Development, and Metabolic and Immune Responses of Holstein Male Calves Fed Milk Through StepDown and Conventional Methods. J Dairy Sci 90, 3376-3387

Khan MA, Lee HJ, Lee WS, Kim HS, Kim SB, Ki KS, Ha JK, Lee HG, Choi YJ (2007b) Pre- and Postweaning Performance of Holstein Female Calves Fed Milk Through Step-Down and Conventional Methods. J Dairy Sci 90, 876-885

Longenbach Jl, Heinrichs AJ (1998) A review of the importance and physiological role of curd formation in the abomasum of young calves. Anim Feed Sci Technol 73, 85-97

Miller SP, Wilton JW, Pfeiffer WC (1999) Effects of milk yield on biological efficiency and profit of beef production from birth to slaughter. J Anim Sci 77, 344-352

Quigley JD, Wolfe TA, Elsasser TH (2006) Effects of Additional Milk Replacer Feeding on Calf Health, Growth, and Selected Blood Metabolites in Calves. J Dairy Sci 89, 207-216

Robison OW, Yusuff MKM, Dillard EU (1978) Milk Production in Hereford Cows I. Means and Correlations. J Anim Sci 47, 131-136

StatSoft (2009) STATISTICA Version 9. StatSoft Inc., Tulsa, OK, USA

Stull C, Reynolds J (2008) Calf Welfare. Vet Clin North Am Food Anim Pract 24, 191-203

Sweeney BC, Rushen J, Weary DM, de Passillé AM (2010) Duration of weaning, starter intake, and weight gain of dairy calves fed large amounts of milk. J Dairy Sci 93, 148-152

Van Soest PJ, Robertson JB, Lewis BA (1991) Methods for Dietary Fiber, Neutral Detergent Fiber, and Nonstarch Polysaccharides in Relation to Animal Nutrition. J Dairy Sci 74, 3583-3597

Winter KA (1978) Response to weaning at two to five weeks of age by the young dairy calf. Can J Anim Sci 58, 377-383 